\title{
Do we need certified medical teachers in medical schools: An educator's self-reflective questionnaire-based survey at Universiti Sains Malaysia
}

\author{
Shahid Hassan ${ }^{1}$, Zafar Ahmed ${ }^{2}$ and Ahmad Fuad Abdul Rahim ${ }^{1}$ \\ ${ }^{1}$ Department of Medical Education/Otorhinolaryngology, School of Medical Sciences, Universiti Sains Malaysia \\ ${ }^{2}$ Department of Community Medicine, Faculty of Medicine, Universiti Kebangsaan Malaysia
}

\begin{abstract}
Background: Faculty's role as educators is over looked in clinical education, even though the teaching has a direct reflection of performance of clinical competence and professional development of graduating doctors. Two major problems of clinical education are the lack of uniform teaching and learning strategies in postgraduate as well as later years of undergraduate clinical teaching and the professional development of faculty in teaching in medical institutions.

Objective: The survey has two major objectives. First objective was to know about the faculty response to a survey on teaching while trying to create awareness for teaching and research in teaching. The second objective was to know the faculty members' understanding with principles of learning and teaching with strengths and weaknesses of respondents' performance in clinical teaching on completing The Educator's Self-Reflective Inventory (ESRI).
\end{abstract}

Method: The ESRI was administered to approach 214 faculty members in SMS at USM. Appraisal of selfreflection inventory as medical teacher and personal development with respect to challenges, opportunities, innovations and need assessment of teaching were explored in response to 35 items grouped in 5 clusters through a questionnaire-based survey utilizing ESRI.

Result: Statistical analysis of respondent's data indicates a mixed response with lab-based disciplines $54.54 \%$ followed by surgical-based disciplines $50 \%$ and medical-based disciplines $30 \%$. Individual discipline best response is received from Plastic Surgery and ORL-HNS (100\%) and Hematology (77.77\%). A result of individual item response in each cluster WAS also analyzed.

Conclusion: The survey evaluated the faculty's response to ESRI and concern shown to develop their abilities as teachers and researchers in clinical teaching. However, the initial response suggested the need for more survey to continue creating the awareness for faculty development and research in teaching. Conclusion drawn from analysis of each items in inventory is encouraging for teaching in medical education.

Key Words: Clinical teaching, research in teaching, educators, awareness, professional development 


\section{Introduction}

The quality of healthcare is influenced by how medicine is taught. The quality of medical practice therefore hinges on the medical curriculum taught and the quality of teachers involved. It is believed that the institutions inadequately practicing faculty development in teaching and research have been facing the problems of producing promising academic physicians capable of continuing quality medical teaching. Research in medical education is as important as ingredients of good teaching. Research has substantially contributed to bridge the gap between educational theories and the practice of medical education [1]. Most importantly, research provides legitimate evidence to stakeholders on which to make educational decisions [2]. Currently the practice of innovative curriculum as a change in educational policies adopted by many medical institutions are the outcome of quantitative as well as qualitative research in medical education. The era of personal opinions in making educational decisions though practiced over the years has no place in pedagogic policies. Current trend in practice of medical education relies on authentic and evidence-based research findings. "Trustable research findings" in place of personal opinions is now the basis of educational management and decision-making [3]. Ingredients of good teaching and research in teaching by right needs certified medical teachers in medical institutions?. Formal training in teaching is not normally practiced in medical education. On the contrary, it has been noted that the criteria of inducting teaching faculty in a medical school is primarily based on expertise of a person's field of specialization rather than his/her credentials as an educator.

Faculty's role as educators is over looked in clinical education, even though teaching in medical education directly reflects on graduating doctor's clinical competence and professional development. Continuous good teaching environment is imperative to promote students development as continuing learners. It is also considered vital for medical teachers in keeping with their continuous professional development [4]. Clinical education requires role model and experienced in clinical teaching educators in medical institutions. A thematic review of the literature about teaching and learning in clinical setting however, found that clinical teaching is 'variable, unpredictable, immediate and lacks continuity [5]. Who will decide on good or bad teaching is more so important in clinical teaching. Learner's (students) feedback is the driving force for good teaching in clinical education. However, a survey of students' perception of 'good' and 'bad' teaching concluded that teachers' interpersonal behavior, how carefully they prepare and plan their teaching and their ability to run a session well determined their worth as clinical teacher [6].

Problem based learning (PBL) approach with SPICES model is the curriculum practiced in undergraduate medical education in School of Medical Sciences in University Saints Malaysia. However, the entire postgraduate teaching and later years of undergraduate teaching in SMS at USM has no laid down teaching strategy established by the department of medical education like the small group PBL methods of teaching practiced in early years of undergraduate medical education. Although clinical teachers are advocated to adapt problem solving learning (PSL) approach, it is not defined for its method and underlying principles of learning in clinical teaching as evident as certain number of steps of small group tutorials in PBL. PSL approach with clinical reasoning skills is though claimed in later years of undergraduate clinical education, the model is very loosely applied in Phase III (clinical years 4 and 5) of undergraduate teaching, as well as in postgraduate teaching. Teaching strategies are mostly left to the discretion of individual 
discipline without a central monitoring. The question often raised is that after acquiring an evidence-based method of clinical teaching (PBL) in Phase I (year 1) and Phase II (year 2 and 3) of undergraduate teaching why the clinical teaching in Phase III (year 4 and 5) is not practiced with a uniformly selected learning model in problem solving skills (PSS) like PBL. Faculty awareness towards lack of uniform teaching and learning strategies in postgraduate and in later clinical years of undergraduate clinical teaching and the professional development of medical teachers are the burning issues for faculty development in institutions delivering medical education. To explore and to create awareness for professional development in teaching and research-inteaching among the academic physicians in SMS, appraisal of educator's self-reflection is considered essential. An inventory for evaluation of educators' self-reflection (ESR) has been developed as a step forward to address these issues.

\section{Material and Methods}

An Educator's Self-reflective Inventory (ESRI) to evaluate faculty for their teaching skills as academic physicians was developed and administered to 214 faculty members in SMS. ESRI was created with five clusters covering various attributes of an educator in a teaching medical institution. The main objective of this survey was that all those completing the inventory would find it an opportunity to have self-appraisal of their performance as an educator exploring their strengths and weaknesses in clinical teaching. Inventory was specially designed to establish faculty member's abilities/shortcomings as a medical teacher beyond a range of routine teaching. Reflecting on performance by responding to a series of structured items in inventory was expected to help the faculty to explore their current status as educators in medical teaching with clues to suggest corrections, which are indicated in items shown on self-development plan in teaching in the last cluster of this inventory.

\section{Result}

Over all, the best response is reported from labbased disciplines $54.54 \%$ followed by surgicalbased disciplines $50 \%$ and medical-based disciplines $30 \%$ (see tables 1-3). The most unexpected response is received from the faculty of Obstetrics and Gynecology department $(0.00 \%$, see table 1) followed by the Department of internal medicine (13.33\%, see table 2 ). Most of the lab-based disciplines have responded well (see table 3). Individual discipline best response is received from Plastic Surgery $(>100 \%$ since one member who was on leave has also completed the inventory) followed by ORL-HNS (100\%) and Hematology (77.77\%). Results of individual item in each of the 5 clusters are analyzed for frequency of structured responses (see tables 49) obtained from 56 respondents. 
Table 1: Number of questionnaires administered vs. number of respondents in surgical based disciplines in SMS, USM.

\begin{tabular}{cccccc}
\hline No & Department & $\begin{array}{c}\text { Faculty } \\
\text { members }\end{array}$ & On leave + sabbatical & Respondents & Percentage \\
\hline 1 & Surgery & 12 & $02+0$ & 03 & $30.0 \%$ \\
\hline 2 & Obs \& Gynea & 10 & $04+01$ & 00 & $0.0 \%$ \\
3 & Orthopedic & 16 & $03+01$ & 04 & $33.33 \%$ \\
4 & Neurosurgery & 08 & $03+0$ & 02 & $40.0 \%$ \\
\hline 5 & Plastic Surgery & 04 & $01+0$ & 04 & $>100 \%$ \\
6 & ORL-HNS & 12 & $01+0$ & 11 & $100 \%$ \\
7 & Ophthalmology & 10 & $04+01$ & 02 & $40.0 \%$ \\
8 & Anesthesia & 13 & $05+01$ & 03 & $42.85 \%$ \\
\hline \multicolumn{7}{l}{$\begin{array}{l}\text { Total } \\
\text { Total number of respondents/Total No of staff present on duty at }\end{array}$} \\
time of administering the ESRI questionnaires & 29 & $50.00 \%$ \\
\hline
\end{tabular}

Table 2: Number of questionnaires administered vs. number of respondents in medical-based disciplines in SMS, USM.

\begin{tabular}{lccccc}
\hline No & Department & $\begin{array}{c}\text { Questionnaires } \\
\text { administered }\end{array}$ & $\begin{array}{c}\text { No of staff on leave }+ \\
\text { sabbatical }\end{array}$ & $\begin{array}{c}\text { Total No of } \\
\text { respondents }\end{array}$ & $\begin{array}{c}\text { Percentage } \\
\text { respondents }\end{array}$ \\
\hline 1 & Psychiatry & 09 & $02+0$ & 04 & $57.14 \%$ \\
\hline 2 & Pediatric Med. & 20 & $06+01$ & 03 & $23.09 \%$ \\
\hline 3 & Internal Med. & 20 & $05+0$ & 02 & $13.33 \%$ \\
\hline 4 & Com Med. & 21 & $03+1$ & 07 & $41.17 \%$ \\
\hline 5 & Family Med. & 11 & $03+00$ & 02 & $25.00 \%$ \\
\hline $\begin{array}{l}\text { Total } \\
\text { The total number of respondents/Total No of staff present on duty at }\end{array}$ \\
time of administering the ESRI questionnaires
\end{tabular}

Table 3: Number of questionnaires administered vs. number of respondents in lab-based disciplines in SMS, USM.

\begin{tabular}{cccccc}
\hline No & Department & $\begin{array}{c}\text { Questionnaires } \\
\text { administered }\end{array}$ & $\begin{array}{c}\text { No of staff on leave + } \\
\text { sabbatical }\end{array}$ & $\begin{array}{c}\text { Total No of } \\
\text { respondents }\end{array}$ & $\begin{array}{c}\text { Percentage } \\
\text { respondents }\end{array}$ \\
\hline 1 & Hematology & 11 & $01+01$ & 07 & $77.77 \%$ \\
2 & Histopathology & 07 & $02+01$ & 01 & $25.00 \%$ \\
3 & Chemical Path. & 11 & $02+00$ & 03 & $37.50 \%$ \\
4 & Microbiology & 12 & $05+00$ & 04 & $57.14 \%$ \\
5 & Immunology & 05 & $00+01$ & 03 & $75.00 \%$ \\
\hline \multicolumn{2}{l}{$\begin{array}{l}\text { Total } \\
\text { The total number of respondents/Total No of staff present on duty at }\end{array}$} \\
time of administering the ESRI questionnaires
\end{tabular}


Table 4: Respondents commitments to structured response on items about their training and experience in teaching

\begin{tabular}{|c|c|c|c|c|}
\hline \multicolumn{5}{|c|}{ Cluster No 1: Training and experience as a clinical teacher: $n=56(100 \%)$} \\
\hline No & Items & Yes & No & Not Sure \\
\hline 1 & $\begin{array}{l}\text { I have acquired formal training in teaching with diploma in } \\
\text { medical education besides specialization in my discipline }\end{array}$ & $\begin{array}{c}2 \\
(3.6 \%)\end{array}$ & $\begin{array}{c}45 \\
(80.0 \%)\end{array}$ & $\begin{array}{c}9 \\
(16.1 \%)\end{array}$ \\
\hline 2 & $\begin{array}{l}\text { I have acquired no formal training in teaching and my teaching } \\
\text { style is emulation of role model teachers of my student days }\end{array}$ & $\begin{array}{c}46 \\
(82.2 \%)\end{array}$ & $\begin{array}{c}0.00 \\
(0.00 \%)\end{array}$ & 10 (17.9\%) \\
\hline 3 & $\begin{array}{l}\text { My inspiration in teaching comes from role model senior/peer } \\
\text { lecturers of my institution }\end{array}$ & $\begin{array}{c}10 \\
(17.9 \%)\end{array}$ & $\begin{array}{c}9 \\
(16.1 \%)\end{array}$ & 37 (66.1\%) \\
\hline 4 & $\begin{array}{l}\text { My teaching experience as lecturer prior to joining School of } \\
\text { Medical Sciences at USM was }>5 \text { years }\end{array}$ & $\begin{array}{c}18 \\
(32.2 \%)\end{array}$ & $\begin{array}{c}32 \\
(57.1 \%)\end{array}$ & $\begin{array}{c}6 \\
(10.7 \%)\end{array}$ \\
\hline 5 & $\begin{array}{l}\text { To improve my teaching skills I often read literature to know } \\
\text { the ingredients of good teaching }\end{array}$ & $\begin{array}{c}11 \\
(19.6 \%)\end{array}$ & $\begin{array}{c}29 \\
(51.8 \%)\end{array}$ & $\begin{array}{c}16 \\
(28.6 \%)\end{array}$ \\
\hline 6 & $\begin{array}{l}\text { To improve my teaching I rely on feedback sought from the } \\
\text { students on my clinical teaching }\end{array}$ & $\begin{array}{c}9 \\
(16.1 \%)\end{array}$ & $\begin{array}{c}20 \\
(35.7 \%)\end{array}$ & $\begin{array}{c}27 \\
(48.2 \%)\end{array}$ \\
\hline 7 & $\begin{array}{l}\text { To improve my teaching I rely on feedback sought from the } \\
\text { peer or/and senior colleagues }\end{array}$ & $\begin{array}{c}18 \\
(32.1 \%)\end{array}$ & $\begin{array}{c}25 \\
(44.6 \%)\end{array}$ & $\begin{array}{c}13 \\
(24.1 \%)\end{array}$ \\
\hline
\end{tabular}

Table 5: Respondents commitments to structured response on items about their preferred methods of clinical teaching

\begin{tabular}{|c|c|c|c|c|}
\hline \multicolumn{5}{|c|}{ Cluster No 2: Practice and methods of clinical teaching: $n=56(100 \%)$} \\
\hline No & Items & Yes & No & Not Sure \\
\hline 8 & $\begin{array}{l}\text { I prefer face to face small group clinical teaching in clinic or } \\
\text { ward }\end{array}$ & $\begin{array}{c}27 \\
(48.2 \%)\end{array}$ & $\begin{array}{c}11 \\
(19.6 \%)\end{array}$ & $\begin{array}{c}18 \\
(32.1 \%)\end{array}$ \\
\hline 9 & $\begin{array}{l}\text { I prefer class room teaching as tutorials with small group } \\
\text { discussion }\end{array}$ & $\begin{array}{c}23 \\
(39.3 \%)\end{array}$ & $\begin{array}{c}10 \\
(17.9 \%)\end{array}$ & $24(42.9 \%)$ \\
\hline 10 & $\begin{array}{l}\text { I prefer class room teaching with lectures in large group } \\
\text { sessions }\end{array}$ & $\begin{array}{c}25 \\
(44.6 \%)\end{array}$ & $\begin{array}{c}9 \\
(16.1 \%)\end{array}$ & $22(39.9 \%)$ \\
\hline 11 & $\begin{array}{l}\text { Problem-based learning as method of teaching in Phase I and II } \\
\text { is helpful to improve my existing teaching skills }\end{array}$ & $\begin{array}{c}5 \\
(8.9 \%)\end{array}$ & $\begin{array}{c}12 \\
(21.4 \%)\end{array}$ & $\begin{array}{c}43 \\
(76.8 \%)\end{array}$ \\
\hline 12 & $\begin{array}{l}\text { Problem-based learning as method of teaching has hindrance } \\
\text { in practice of my teaching skills }\end{array}$ & $\begin{array}{c}26 \\
(46.4 \%)\end{array}$ & $\begin{array}{c}13 \\
(23.2 \%)\end{array}$ & $17(30.4 \%)$ \\
\hline 13 & $\begin{array}{l}\text { Problem-solving learning in Phase III for me is a well } \\
\text { understood approach of learning different from PBL }\end{array}$ & $\begin{array}{c}34 \\
(60.7 \%)\end{array}$ & $\begin{array}{c}10 \\
(17.9 \%)\end{array}$ & $12(21.4 \%)$ \\
\hline 14 & $\begin{array}{l}\text { Problem-solving learning like PBL is not a uniformly practiced } \\
\text { method with similar model of teaching by all disciplines }\end{array}$ & $\begin{array}{c}31 \\
(54.4 \%)\end{array}$ & $\begin{array}{c}11 \\
(19.6 \%)\end{array}$ & $14(25.0 \%)$ \\
\hline
\end{tabular}


Table 6: Respondents commitments to structured response on items about their professional development as an educator

\begin{tabular}{|c|c|c|c|c|}
\hline \multicolumn{5}{|c|}{ Cluster No 3: professional development as an educator: $n=56(100 \%)$} \\
\hline No & Items & Yes & No & Not Sure \\
\hline 15 & $\begin{array}{l}\text { As a clinical teacher and educator I need to develop skills in } \\
\text { medical education and cognitive psychology }\end{array}$ & $\begin{array}{c}34 \\
(60.7 \%)\end{array}$ & $\begin{array}{c}6 \\
(10.7 \%)\end{array}$ & $\begin{array}{c}16 \\
(28.6 \%)\end{array}$ \\
\hline 16 & $\begin{array}{l}\text { I need to know more about principles of learning to improve } \\
\text { my teaching abilities }\end{array}$ & $\begin{array}{c}26 \\
(46.4 \%)\end{array}$ & $\begin{array}{c}21 \\
(37.5 \%)\end{array}$ & $\begin{array}{c}9 \\
(16.1 \%)\end{array}$ \\
\hline 17 & $\begin{array}{l}\text { I need to learn more about learners in order to improve my } \\
\text { clinical teaching skills }\end{array}$ & $\begin{array}{c}43 \\
(76.8 \%)\end{array}$ & $\begin{array}{c}2 \\
(3.6 \%)\end{array}$ & $\begin{array}{c}11 \\
(19.7 \%)\end{array}$ \\
\hline 18 & $\begin{array}{l}\text { I intend to know more about ingredients of good teaching } \\
\text { skills to improve my clinical teacher in my discipline }\end{array}$ & $\begin{array}{c}29 \\
(69.6 \%)\end{array}$ & $\begin{array}{c}1 \\
(1.8 \%)\end{array}$ & $16(28.6 \%)$ \\
\hline 19 & $\begin{array}{l}\text { I also need to develop myself as a competent educator with } \\
\text { some formal courses in medical education }\end{array}$ & $\begin{array}{c}24 \\
(42.9 \%)\end{array}$ & $\begin{array}{c}26 \\
(46.5 \%)\end{array}$ & $6(10.7 \%)$ \\
\hline 20 & $\begin{array}{l}\text { I need to be conversant with research methodology necessary } \\
\text { for researching the topics in medical education }\end{array}$ & $\begin{array}{c}29 \\
(51.8 \%)\end{array}$ & $\begin{array}{c}13 \\
(23.2 \%)\end{array}$ & $\begin{array}{c}14 \\
(25.0 \%)\end{array}$ \\
\hline 21 & $\begin{array}{l}\text { I am interested to undertake research and innovation in } \\
\text { teaching to explore new learning models }\end{array}$ & $\begin{array}{c}30 \\
(53.6 \%)\end{array}$ & $\begin{array}{c}19 \\
(34.0 \%)\end{array}$ & $\begin{array}{c}17 \\
(12.5 \%)\end{array}$ \\
\hline
\end{tabular}

Table 7: Respondents commitments to structured response on items about their development in leading role as an educator

\begin{tabular}{|c|c|c|c|c|}
\hline \multicolumn{5}{|c|}{ Cluster No 4: Preparing for leading role in teaching: $n=56(100 \%)$} \\
\hline No & Items & Yes & No & Not Sure \\
\hline 22 & $\begin{array}{l}\text { I would like to enhance my teaching skills by collaborating } \\
\text { with department of medical education }\end{array}$ & $\begin{array}{c}31 \\
(55.4 \%)\end{array}$ & $\begin{array}{c}9 \\
(16.1 \%)\end{array}$ & $\begin{array}{c}16 \\
(28.6 \%)\end{array}$ \\
\hline 23 & $\begin{array}{l}\text { I would like to enhance my teaching skills by reading medical } \\
\text { education journals }\end{array}$ & $\begin{array}{c}31 \\
(55.4 \%)\end{array}$ & $\begin{array}{c}14 \\
(25.0 \%)\end{array}$ & $\begin{array}{c}11 \\
(19.6 \%)\end{array}$ \\
\hline 24 & $\begin{array}{l}\text { I would like to establish a peer lecturers educator group for } \\
\text { interactive feedback on each other's teaching }\end{array}$ & $\begin{array}{c}51 \\
(86.3 \%)\end{array}$ & $\begin{array}{c}2 \\
(3.6 \%)\end{array}$ & $\begin{array}{c}4 \\
(7.1 \%)\end{array}$ \\
\hline 25 & $\begin{array}{l}\text { I will explore opportunities to do research in educational } \\
\text { projects besides my research in medical sciences }\end{array}$ & $\begin{array}{c}45 \\
(80.4 \%)\end{array}$ & $\begin{array}{c}3 \\
(5.4 \%)\end{array}$ & $\begin{array}{c}8 \\
(14.3 \%)\end{array}$ \\
\hline 26 & $\begin{array}{l}\text { I will readily accept any assignments from the department of } \\
\text { medical education to assist teaching }\end{array}$ & $\begin{array}{c}39 \\
(87.5 \%)\end{array}$ & $\begin{array}{c}2 \\
(3.6 \%)\end{array}$ & $\begin{array}{c}5 \\
(8.9 \%)\end{array}$ \\
\hline 27 & $\begin{array}{l}\text { I would also like to work in leadership role as block/phase } \\
\text { coordinator for PBL in undergraduate teaching }\end{array}$ & $\begin{array}{c}49 \\
(87.5 \%)\end{array}$ & $\begin{array}{c}2 \\
(3.6 \%)\end{array}$ & $\begin{array}{c}5 \\
(8.9 \%)\end{array}$ \\
\hline 28 & $\begin{array}{l}\text { I can competently take the responsibilities of a program } \\
\text { coordinator for postgraduate training in my institution }\end{array}$ & $\begin{array}{c}49 \\
(87.5 \%)\end{array}$ & $\begin{array}{c}1 \\
(1.8 \%)\end{array}$ & $\begin{array}{c}6 \\
(10.7 \%)\end{array}$ \\
\hline
\end{tabular}


Table 8: Respondents commitments to structured responses on items about their vision for personal development plan

\begin{tabular}{|c|c|c|c|c|}
\hline \multicolumn{5}{|c|}{ Cluster No 5: Vision for personal development plan as an educator: $n=56(100 \%)$} \\
\hline No & Items & Yes & No & Not Sure \\
\hline 29 & $\begin{array}{l}\text { Identifying my learning needs in teaching skills I would like to } \\
\text { know more about established educational theories }\end{array}$ & $\begin{array}{c}45 \\
(80.4 \%)\end{array}$ & $\begin{array}{c}5 \\
(8.9 \%)\end{array}$ & $\begin{array}{c}6 \\
(10.7 \%)\end{array}$ \\
\hline 30 & $\begin{array}{l}\text { As continuing clinical learning I would like to know more } \\
\text { educational methods than the one we currently practice }\end{array}$ & $\begin{array}{c}48 \\
(85.7 \%)\end{array}$ & $\begin{array}{c}4 \\
(7.1 \%)\end{array}$ & $\begin{array}{c}3 \\
(5.4 \%)\end{array}$ \\
\hline 31 & $\begin{array}{l}\text { As ingredients of good teaching I would like to be aware of } \\
\text { evidence-based methods in medical education }\end{array}$ & $\begin{array}{c}36 \\
(64.3 \%)\end{array}$ & $\begin{array}{c}11 \\
(19.6 \%)\end{array}$ & $\begin{array}{c}9 \\
(16.1 \%)\end{array}$ \\
\hline 32 & $\begin{array}{l}\text { Allowing critical analysis of my teaching performance I would } \\
\text { like to seek collaborative feedback from students in future }\end{array}$ & $\begin{array}{c}38 \\
(67.9 \%)\end{array}$ & $\begin{array}{c}7 \\
(12.5 \%)\end{array}$ & $\begin{array}{c}11 \\
(19.6 \%)\end{array}$ \\
\hline 33 & $\begin{array}{l}\text { Currently exposed to varying methods of clinical teaching } \\
\text { within my discipline I would like to know if there is an } \\
\text { authentic problem solving learning (PSL) method like PBL }\end{array}$ & $\begin{array}{c}43 \\
(76.4 \%)\end{array}$ & $\begin{array}{c}5 \\
(8.9 \%)\end{array}$ & $\begin{array}{c}8 \\
(14.3 \%)\end{array}$ \\
\hline 34 & $\begin{array}{l}\text { Accepting the fact that I did not receive a formal training in } \\
\text { basic teaching skills, I would like to see tomorrows academic } \\
\text { physician being properly trained in teaching }\end{array}$ & $\begin{array}{c}26 \\
(47.0 \%)\end{array}$ & $\begin{array}{c}15 \\
(26.8 \%)\end{array}$ & $\begin{array}{c}15 \\
(26.8 \%)\end{array}$ \\
\hline 35 & $\begin{array}{l}\text { Looking forward to excel as a medical teacher I would rather } \\
\text { undertake an on-line medical education program to improve } \\
\text { my clinical teaching skills in future }\end{array}$ & $\begin{array}{c}32 \\
(57.1 \%)\end{array}$ & $\begin{array}{c}12 \\
(21.4 \%)\end{array}$ & $\begin{array}{c}12 \\
(21.4 \%)\end{array}$ \\
\hline
\end{tabular}

\section{Discussion}

A questionnaire-based survey-utilizing educator's self-reflective inventory on teaching and its initial evaluation of response is looked on as a predictor to suggest faculty's awareness and desire for professional development as an educator in School of Medical Sciences at USM. Five clusters included in ESRI were training and experience as medical teacher, practice of clinical methods in teaching, professional development as educators, leading role in teaching and vision for personal development plan in teaching. Each cluster has 7 items with three structured responses to choose. To create an environment conducive for completing ESR Inventory, author had released two editorials, one each on faculty development [7] and ingredients of good teaching [8] a week earlier than administering the questionnaire.
These editorials were about author's exclusive experience and observation in clinical teaching and research in teaching in School of Medical Sciences in USM during the last 13 years.

The initial response observed as number of faculty members versus respondents has in a way suggested faculty's pattern and enthusiasm for teaching and professional development as educators (see tables 1-3). An overview of respondents who completed the inventories from each discipline reflects the concern shown for teaching by the faculty members in general and for their meta-cognitive skills in teaching in particular. Difficulties identified in some items in an earlier administered inventory as a pilot study were validated in current study. Each cluster presented as a table in this article (see tables 4-8) 
put together make the composite version of ESR inventory ready for use.

Descriptive statistics was utilized to analyze the frequency distribution of each of the seven items of five clusters of a structured ESR inventory in this study. Cluster 1 explored the teaching experience and the medical education background of academic physician in SMS at USM (see table 4). With regards to formal training in teaching majority lecturers rather admitted of their informal training in teaching influenced by teaching styles emulated from the role model teachers of their student's days as responded by 46 (82.2\%) lecturers versus emulated senior/peer lecturers responded by a small number of 10 (17.9\%) lecturers. However, only 2 (3.6\%) faculty members claimed to have obtained diploma in medical education. Majority faculty members do not seek the feedback on their performance in teaching either from students or peer. Only 9 (16.1\%) lecturers sought feedback from students and 18 (32.1\%) from peer. The experience in teaching prior to joining USM has been claimed to be more than five years by 18 (32.2\%) lecturers. Only a small number of lecturers 11 (19.6\%) believed in improving the teaching skills by reading literature on teaching and learning. A selfappraisal of teaching performance achieved by respondents on completing 4 clusters of ESR inventory have in fact revisited some of those items again in cluster 5 on personal development plan, which shows their commitments to few interesting pledges reiterated.

Practice and methods of clinical teaching explored in clusters 2 (see table 5) showed comparable preferences for face-to-face ambulatory clinical teaching 27 (48.2\%) versus, tutorials as small group discussion 23 (39.3\%) and class room teaching as lectures 25 (44.6\%). PBL considered helpful to polish teaching skills has been suggested only by 5 (8.9\%) lecturers compared to see it as a hindrance to improving the teaching skills, observed by 26 (46.4\%) lecturers. However, the majority lecturers are indecisive on this issue. Precise role of teacher as facilitator in a studentcentered PBL model needs elaborations to overcome this misconception among the teaching faculty. It is important for every lecturer to comprehend their belief in PBL to play their effective role as a tutor in small group discussions of PBL tutorials, which do promotes teaching skills though differently than traditional lectures. Traditional (formal) lectures are considered inadequate to promote analytic clinical reasoning skills. However, formal lectures do have a place in teaching even in PBL since a block/unit in PBL needs few introductory lectures to initiate the organ-system blocks in PBL. Problem solving learning has been claimed by $34(60.7 \%)$ lecturers to be a well-understood method for its intent, which is different from PBL. PSL is not being practiced with an authentic model like PBL is responded by 31 (54.4\%). Faculty member's reflection and insight for PBL and PSL as methods of teaching is encouraging to note. A major teaching strategy adopted in undergraduate medical education is based on PBL whereas postgraduate learning primarily an apprenticeship- program relies on problem-solving skills with ingredients of clinical learning described in Barrows' taxonomy of PBL [9]. A PSL model therefore, should focus on structuring the knowledge in clinical contents, clinical reasoning process, motivation and self-directed leaning. For a competent learning, problem-solving skills are important to be developed. However, PSL demands authentic training and in-vivo than invitro assessment of clinical competence [10]. To address these issues in medical education, it demands professional development of clinicians directly involved in teaching and assessment. A unit of excellence in clinical education (within the domain medical education) can address these issues precisely well. The unit can work as resource center to implement problem solving learning as an approach with its real meaning and method to explore a model for problem solving 
skills, which is agreeable by all disciplines both for undergraduate as well as postgraduate teaching in future. Currently in problem solving learning the basic assumption has vague evidence for real world and is open to questions, contrary to PBL approach, which is firmly grounded in theory and evidence [11].

Desire for professional development in teaching committed in cluster 3 (see table 6) has been acknowledged with needs assessment towards skills in medical education and cognitive psychology by as many as $34(60.7 \%)$ lecturers. Needs of undertaking research in teaching and knowledge in research methodology to accomplish research in medical education has also been appreciated by majority members 29 (51.8\%) and 30 (53.6\%) respectively. Enthusiastic clinical teachers can find more opportunities for innovation and research in teaching while trying to explore new teaching models in problem solving skills. Author strongly believes that clinicians are in best position to explore innovative methods in teaching and learning [12], provided they undertake research and faculty development in teaching more seriously. Research in this field is not the responsibility of medical educationist alone, clinicians directly engaged in routine clinical teaching have more opportunities for research in teaching in which direct feedback from the students plays an important role. However, the hierarchy's encouragement and incentives to clinicians to perform research in teaching is a key to this practice. A very well guided collaboration among medical educationists and clinical faculty members in an institution can boost faculty development in teaching as well as research in teaching.

Further in cluster 3, knowledge to know about learners, responded by 43 (76.8\%) lecturers, principles of learning by $26(46.4 \%)$ and ingredients of good teaching by $29(69.6 \%)$ has been applauded by a number of lecturers and is interesting to note. The ultimate desire shown to acquire courses in medical education by 24 $(42.8 \%)$ lecturers is also encouraging. The two objectives in designing this inventory were; 1) To know the discipline-wise faculty member's response to a survey on teaching with an intention to create awareness for ingredients of good teaching and research in teaching. Evaluation of initial response to inventory with this intention established the fact that how much do the faculty knows about what they teach and what they need to teach. However, a poor turnout in some disciplines (see tables1-3) is considered faculty's indifferent approach in handling the tripod of their practice as researchers, teachers and clinicians in a balance manner. 2) Appreciation of importance of principles of learning and teaching in general with strengths and weaknesses of respondent's performance in clinical teaching as an outcome of reflective-abilities determined in this inventory was the other objective. A respondent can evaluate his/her performance as an educator with strong and weak links in routine clinical teaching as he/she moves from cluster 1 to cluster 5 while completing this inventory. Commenting through structured responses on one's personal development plan to excel in teaching is to further this objective again in cluster 5.

With regards to making efforts to promote his/her role of an educator and to take responsibilities in leading roles as educators is determined in cluster 4 (see table 7). 31 (55.4\%) members have shown intention to enhance knowledge in medical education either by collaborating with the department of medical education or reading literature in medical education. Further promotion in medical education to develop a peer group for interactive feedback on teaching and research in teaching has also been wished by a high number of lecturers 51 (81.6\%) and 45 (80.4\%) respectively and is considered encouraging promoting quality physician educators in future. Readiness to take 
responsibilities in leading role as block/phase coordinator for undergraduate teaching or program coordinator for postgraduate teaching shown by a high number, $49(87.5 \%)$ of lecturers in each item respectively is promising for teaching in this institution.

Vision for personal development plan has been equally promising as shown in response to items in cluster 5 (see table 8). Majority faculty members opted to know more about learning theories responded by 45 (80.4\%), more than one educational method responded by 48 (85.7\%) and evidence-based educational methods responded by $36(64.3 \%)$.

Lecturers readily open to criticism on teaching from students is seen a step forward to practicing new trends in current culture of teaching in this institution, as opted by a number of lecturers 38 (67.9\%). Though committed to have understood the underlying concepts in PSL and PBL and their precise and meaningful difference in response to items 13 and 14 of cluster 2, the desire shown by 43 (86.4\%) lecturers in response to item 33 of cluster 5 suggest their curiosity in knowing more about PSL. Ultimately willing to do an on-line course in medical education by 32 (57.1\%) lecturers and to see tomorrow's doctor trained in teaching skills in their curriculum by 26 (47.0\%) lecturers is more than the expected outcome of the study. This observation is contrary to the impression gathered about the prevalent trend of academic physician's declining interest in teaching in general. Exploring the importance paid to metacognitive skills by faculty members is suggested by the void inventories returned by some disciplines. Critically seen it indicates the faculty's cold shoulder response to participate in a survey (research) that was meant to promote their interest and professional development in teaching.

The survey has rung the bell to at least acknowledge the faculty's interest towards what we are teaching and what we need to teach as educators. Besides, it has also established the desire of faculty to develop their skills in clinical teaching and research in teaching. Comments made on items with structured responses on one's personal development plan with respect to challenges, opportunities, new ideas and need assessment of teaching is essentially required by an educator to excel in a teaching medical institution [13]. Many of those who did not bother to return the inventory have rather raised a number of questions. Are we really too busy or simply lazy to respond? Are we failing to keep up the balance required in tripod of practice as researcher, teacher and clinician? Or do we lack a research culture in teaching? Difficulty in some items identified in pilot study is though rectified here, author would like to concede that some of those items were not easy to understand, simply because the issues discussed in those items were new for many clinical teachers involved in this survey. For example, PSL versus PBL were difficult for many to define for its truly understood principles and intended strategies in clinical teaching. This highlights the need for periodic workshops and discussions on those issues as often as possible.

The two outcomes achieved through this survey included, the current status of faculty's interest in teaching as well as in research and the subsequent plan of formal training of faculty as certified medical teachers through courses that can be initiated by medical education department of School of Medical Sciences in the future. Based on these outcomes a recommendation put forward here is to establish a discussion forum each for medical, surgical and lab-based disciplines, which can be utilized by component disciplines to share their teaching experiences to finally agree to a teaching strategy or model in problem-solving skills like the one practiced in problem analyzing skills in PBL model. Experience of existing teaching models practiced versus an innovative model 
either created or adopted from literature in problem-solving skills can mutually be discussed in a collaborative manner in these forums. For instance, a uniformly practiced model in PSL like PBL with good ground of evidence from published literature. Finally, addressing the outcomes of this study will enable the department of medical education to play a proactive role to offer short courses and workshops in clinical teaching. Alternatively, an on-line professional diploma in medical education may be the other option that will promote academic physicians in clinical teaching as educators. This will also promote clinical teachers to professionally develop their knowledge and skills for clinical teaching incorporated with principles of adult learning. Attitude shown to know more about the learners and to optimize the learning with students and peer's feedback is good news for teaching in any medical institution.

\section{Conclusion}

Educator's Self-reflective Inventory has been carefully designed to create awareness and to promote professional development of faculty members as educators, monitored with selfassessment and required teaching skills in clinical education. The first important objective of this inventory was to know the faculty members awareness towards ingredients of good teaching and research in teaching. Appreciation of importance of principles of learning on completing the inventory as self-reflective appraisal was the other objective. These two objectives have been achieved in current survey that has evaluated the faculty member's response towards completing an inventory to assess their own performance in teaching and to show their concern about what they are teaching and what they need to be teaching to perform better as clinical teachers and researchers in teaching.
Conclusion drawn from analysis of items in each of the five clusters have provided respondents with an opportunity to reflect on their performance in teaching in first 4 clusters, and to relook into it again in cluster 5 to make pledges as personal development plan with some interesting commitments reiterated. It has also explored the needs of formal training of faculty members as certified medical teachers through on-line courses offered by the department of medical education in future.

\section{References}

1. Harden RM. Approaches to research in medical education. Med Educ 1986; 20:522-531

2. Majumder MAA. Issues and priorities of medical education research in Asia. Annals Academy of Medicine 2004; 33 (2): 257-263

3. Jason $\mathrm{H}$. The importance and limits of evidence medical education. Educ Health 2000; 13:9-13

4. Davis D, O'Brien TMA, Freemantle N, Wolf FM, Taylor-Vaisey A. Impact of formal continuing medical education: Do conferences, workshops, rounds, and other traditional continuing education activities change physician behaviour or health care outcomes? JAMA, 1999; 282 (9): 867-874. http://dx.doi.org/10.1001/jama.282.9.867

5. Irby DM. Teaching and learning in ambulatory care settings: a thematic review of the literature. Acad Med 1995; 70 (10): 898-931

6.Metcalfe DH, Mathura M. Students' perceptions of good and bad teaching: report of a critical incident study. Med Educ 1995; 29:193-197

7. Hassan S. Faculty development with research and innovation in medical teaching. Pakistan Journal of Otolaryngology, 2010; 26 (1): 1-2.

8. Hassan S. Exploring the ingredients of good teaching in postgraduate medical education. 
Pakistan Journal of Otolaryngology, 2008; 24 (3): 51-52.

9. Vrenon DTA, Blake RL. Does problem-based learning work? A meta - analysis of evaluative research. Academic Medicine, 1993; 68: 550-63. http://dx.doi.org/10.1097/00001888-19930700000015

10. Kroboth FJ, Hanusa BH, Parker S, Coulehan JL, Kappor WN, Brown FH, et al. The inter-rater reliability and internal consistency of clinical evaluation exercise. J Gen Intern Med, 1992; 7: 174-179. http://dx.doi.org/10.1007/BF02598008
11. Norman G. Problem-solving skills versus problem-based learning, program for educational development. Perspective for Health Sciences Education in Pedagogue, 1989; Summer Ed: 1-2.

12. Hassan S. Professional development of clinical teachers as educators: role of medical education as discipline. Pakistan Journal of Otolaryngology $2011 ; 27: 1-2$

13. McKimm J. Professional developments for medical educators and clinical teachers: challenges and opportunities. South East Asian Journal of Medical Education, 2009; 3 (2): 3-8.

Corresponding Author: Professor $\mathrm{Dr}$ Shahid Hassan, Medical Education/ Otorhinolaryngology Department, School of Medical Sciences, Universiti Sains Malaysia, Kubang Kerian, 16150 Kota Bharu, Kelantan, Malaysia.

Email: shahid@kb.usm.my,gorshahi@yahoo.com 